\title{
ACTIVITIES OF LOCAL GOVERNMENT INSTITUTIONS ON THE STOLYPIN AGRARIAN REFORM IMPLEMENTATION IN THE TERRITORY OF BELARUS (1906-1914)
}

\author{
Svetlana A. Tolmacheva \\ Belarusian State Pedagogical University named after Maxim Tank, Minsk, Republic of Belarus
}

\begin{abstract}
Introduction. The preparation and implementation of the Stolypin agrarian reform attracted the attention of researchers of the $20^{\text {th }}-21^{\text {st }}$ centuries. However, the interaction of the entire system of already existing and new local government institutions in implementing the reform in Belarus has not become a subject of a special study. The purpose of the article is to prove the interaction of local government institutions within the implementation of the Stolypin agrarian reform in 1906-1914 in the territory of Belarus. Methodology. The sources of the article were legislative acts, as well as the information founded in the archival and published documents. The general scientific and specific historical methods were used there as well as the principles of objectivity, historicism, the value approach. Results. In the early $20^{\text {th }}$ century, a system of local government institutions on the implementation of the government agrarian policy was formed in the Empire. It included land (zemstvo) captains, their district (uyezd) congresses and provincial (guberniya) agencies (prisutstviya). The implementation of the Stolypin agrarian reform required the creation of new institutions - land management commissions. The absence of zemstvo and noble election in the territory of Belarus caused the peculiarities of the formation of the commission staff. Land captains and members of land management commissions carried out explanatory work among the population about the benefits of the transition to farms (khutors) and cuts of lands (otrubs). Based on the information collected by land captains, land management commissions drew up land management plans for the next year, distributed and carried out the work. District congresses and provincial agencies approved land certificates. Conclusion. The success of the reform depended on the coordinated work and cooperation of all elements of the local government system, the prevalence of household land use. The explanatory work carried out by land captains and members of land management commissions, the promotion of sale of banking lands, allotment of land units to ownership and the transition to new household forms received support of the population. All those facts ensured the success of the implementation of the Stolypin reform in the territory of Belarus.
\end{abstract}

Key words: Belarus, Stolypin agrarian reform, land management commission, land captain, provincial agencies.

Citation. Tolmacheva S.A. Activities of Local Government Institutions on the Stolypin Agrarian Reform Implementation in the Territory of Belarus (1906-1914). Vestnik Volgogradskogo gosudarstvennogo universiteta. Seriya 4. Istoriya. Regionovedenie. Mezhdunarodnye otnosheniya [Science Journal of Volgograd State University. History. Area Studies. International Relations], 2021, vol. 26, no. 2, pp. 107-118. (in Russian). DOI: https://doi.org/ 10.15688/jvolsu4.2021.2.8

\section{ДЕЯТЕЛЬНОСТЬ МЕСТНЫХ ОРГАНОВ УПРАВЛЕНИЯ ПО РЕАЛИЗАЦИИ СТОЛЫПИНСКОЙ АГРАРНОЙ РЕФОРМЫ НА ТЕРРИТОРИИ БЕЛАРУСИ (1906-1914 гГ.)}

\author{
Светлана Александровна Толмачева \\ Белорусский государственный педагогический университет им. Максима Танка, \\ г. Минск, Республика Беларусь
}


Аннотация. Введение. Подготовка и реализация Столыпинской аграрной реформы привлекали внимание исследователей XX-XXI веков. Однако совместная работа уже существовавших и новых органов местного управления по проведению в жизнь реформы на территории Беларуси не стала предметом специального исследования. Цель статьи - показать взаимодействие местных органов управления в процессе реализации Столыпинской аграрной реформы в 1906-1914 гг. на территории Беларуси с учетом региональных особенностей. Методология. Источниковую базу статьи составили законодательные акты, информация, извлеченная из архивных и опубликованных документов. При подготовке статьи были реализованы принципы историзма, объективности и ценностного подхода, а также общенаучные и специально-исторические методы (историкосистемный, историко-сравнительный, историко-генетический и др.). Результаты. В начале ХХ в. в империи сложилась система местных органов государственного управления по реализации аграрной политики: земские начальники, их уездные съезды и губернские присутствия. Для проведения в жизнь столыпинской реформы были созданы новые органы управления - землеустроительные комиссии. Отсутствие земств и дворянских выборов в белорусских губерниях стало причиной особенностей формирования кадрового состава комиссий. Земские начальники и члены комиссий проводили разъяснительную работу о пользе перехода на хутора и отруба. На основании собранных земскими начальниками сведений землеустроительные комиссии составляли планы землеустройства, распределяли и выполняли землеустроительные работы. Уездные съезды земских начальников и губернские присутствия утверждали документы на землю. Заключение. Согласованная работа и взаимодействие всех структурных элементов системы местного государственного управления, преобладание подворного землевладения в белорусских губерниях стали причиной успешной реализации реформы. Проводимая земскими начальниками и членами землеустроительных комиссий разъяснительная работа, содействие при продаже банковских земель, выделе наделов в собственность и переходе к новым формам ведения хозяйства встречали отклик у населения. В результате основные задачи по реформированию аграрных отношений на территории Беларуси в основном были решены.

Ключевые слова: Беларусь, Столыпинская аграрная реформа, землеустроительная комиссия, земский начальник, губернское присутствие.

Цитирование. Толмачева С. А. Деятельность местных органов управления по реализации Столыпинской аграрной реформы на территории Беларуси (1906-1914 гг.) // Вестник Волгоградского государственного университета. Серия 4, История. Регионоведение. Международные отношения. -2021. - Т. 26, № 2. - С. 107-118. DOI: https://doi.org/10.15688/jvolsu4.2021.2.8

Введение. В результате трех разделов Речи Посполитой (1772, 1793 и 1795 гг.) территория современной Беларуси вошла в состав Российской империи. В начале ХХ в. она включала 35 белорусских уездов, в состав которых входили 4 из 7 уездов Виленской губернии, 5 из 11 Витебской, 6 из 9 уездов Гродненской, вся Минская (9 уездов) и Могилевская (11 уездов) губернии. В официальных документах того времени иногда употреблялся термин «северо-западные губернии», под которым подразумевались 6 губерний: Виленская, Витебская, Гродненская, Ковенская, Минская и Могилевская.

Проведение реформ во второй половине XIX - начале XX в. имело на территории Беларуси значительные отличия, связанные с политическими и экономическими особенностями региона. После восстания 1863-1864 гг. правительство настороженно относилось к представителям местного дворянства римско-католического вероисповедания, которых в западных губерниях было большинство. В связи с этим реализация земской реформы 1864 г. была отложена на неопределенное время. Только в 1911 г. земства были введены на территории Витебской, Минской и Могилевской губерний. В Виленской и Гродненской губерниях реформа так и не была проведена. В результате некоторые функции, выполнявшиеся земствами, перекладывались на другие органы местного управления, а должностные лица, избираемые земствами, назначались администрацией.

Свои особенности имели и поземельные отношения. Так, в Виленской, Гродненской и Минской губерниях у крестьян преобладало подворное землевладение, а в Витебской и Могилевской - общинное. Это отразилось на реализации аграрной политики правительства в крае. Цель статьи - показать взаимодействие местных органов управления по реализации Столыпинской аграрной реформы в 1906-1914 гг. на территории Беларуси с учетом региональных особенностей.

Методы и материалы. Источниковую базу статьи составили законодательные акты, 
информация, извлеченная из архивных и опубликованных документов. При подготовке статьи были реализованы принципы историзма, объективности и ценностного подхода, а также применены как общенаучные, так и специально-исторические методы. Так, историкосистемный метод дал возможность выявить систему действовавших в начале XX в. органов управления, проводивших аграрную политику правительства на местах, и то, как новые органы (землеустроительные комиссии) включились в эту систему. Историко-сравнительный метод позволил показать общее и специфическое в формировании кадрового состава землеустроительных комиссий, а также результаты деятельности всей системы. Использование историко-генетического метода позволило проследить изменение функциональных обязанностей местных органов, peализовавших реформу, в связи с изданием новых законодательных актов и циркуляров.

Подготовка и реализация Столыпинской аграрной реформы привлекали внимание исследователей XX-XXI веков. В дореволюционной историографии реформу критиковали и справа, и слева. При этом публикации главным образом имели не аналитический, а оценочный характер, а результаты деятельности местных органов по реализации реформы раскрыты не были. Историки советского периода в целом критиковали политику царского правительства в аграрной сфере и доказывали низкую эффективность предпринимавшихся мер. При этом в советской историографии был накоплен значительный фактологический материал по реализации и основным итогам реформы, рассмотрены отдельные аспекты деятельности органов местного управления, однако механизм реализации реформы не получил должного освещения. В современной исторической науке появились новые тенденции и методологические подходы в изучении аграрной политики правительства. В научный оборот вводятся новые документы и материалы, раскрываются региональные особенности. Так, Г.П. Волгирева и О.А. Пасько не только провели анализ различных сторон механизма обеспечения реформы, но и исторические параллели между реформами начала и конца XX в. в России. Особое внимание авторы уделили проведению столыпинской ре- формы в Томской губернии [1]. В статье Т.В. Емельяновой раскрыт механизм работы губернских и уездных землеустроительных комиссий, приводятся характеристики некоторых членов комиссий Могилевской и Витебской губерний [9]. Деятельности землеустроительных комиссий на территории Беларуси посвящена кандидатская диссертация и ряд публикаций К.Ю. Таранович [20]. Перечень подобных работ можно продолжать. Однако взаимодействие всей системы уже существовавших и новых органов местного управления по реализации Столыпинской аграрной реформы на территории Беларуси не стало предметом специального исследования, что подчеркивает актуальность данной статьи.

Анализ. В начале $\mathrm{XX}$ в. в Российской империи обострились поземельные отношения. Крестьянское малоземелье, чересполосица при существовании крупных помещичьих латифундий требовали срочного решения аграрного вопроса. Поэтому в 1902 г. было созвано Особое совещание о нуждах сельскохозяйственной промышленности. Для обсуждения и сбора предложений на местах создавались уездные и губернские комитеты о нуждах сельскохозяйственной промышленности. Комитетами белорусских губерний отмечалась необходимость оказания агрономической помощи, создания складов сельскохозяйственной техники, обучения крестьян внедрению улучшенных форм ведения хозяйства, а также ликвидации малоземелья, чересполосицы, сервитутов через упрощение приобретения, обмена и отграничения земельных участков и др. Предлагалось и создание особых местных органов, способствующих новым преобразованиям на селе [21]. Весь накопленный материал стал фундаментом для разработки аграрной реформы во главе со П.А. Столыпиным.

Процесс перехода к хуторам и отрубам на территории Беларуси зародился еще до столыпинской реформы. Так, на границе Витебской, Могилевской и Смоленской губерний такое движение началось еще во второй половине 70-х гг. ХІХ века. До 1904 г. только здесь были разверстаны и расселены 287 поселений общей площадью 30235 дес., из которых были созданы 3043 хутора. Показательно, что в соответствии с тогдашним законо- 
дательством решение принималось на сельском сходе единогласно [8, с. 672-673]. Именно это требование закона препятствовало переходу к оптимальным формам хозяйствования. Например, Гродненское губернское присутствие в начале 1906 г. не разрешило крестьянам дер. Кублики Кобринского уезда Гродненской губернии расселиться на хутора, отметив, что при подворном владении крестьян переход от шнурового к хуторскому землевладению разрешен только при единогласном приговоре общины, рассмотренном и утвержденном губернским присутствием [4, л. 1-2]. Подобных примеров можно привести много, что доказывает необходимость реформирования законодательства. При этом до реформы именно крестьяне выступали инициаторами хуторского расселения, но не встречали поддержки у местной администрации.

В начале XX в. система органов местного государственного управления, реализовавших аграрную политику правительства, включала следующие элементы: земские начальники, их уездные съезды и губернские присутствия. Эта структура была создана на основе Положения о земских участковых начальниках от 12 июля 1889 г. [17, № 6196]. С 1906 г. началось формирование новых органов - уездных и губернских землеустроительных комиссий.

Земские участковые начальники были чиновниками, обладавшими административными и судебными полномочиями на территории своего участка (обычно от 3 до 8 участков в уезде). Земские начальники уезда составляли уездный съезд. Одной из их главных задач было разрешение вопросов землепользования и землевладения, а также поземельных споров как между крестьянами, так и с представителями других сословий, проживавших в участке. Утверждались постановления этих чиновников уездными съездами земских начальников и губернскими присутствиями. Последние являлись коллегиальными органами, пришедшими на смену губернским по крестьянским делам присутствиям. Возглавляемые губернатором, они реализовывали политику правительства по отношению к сельскому населению и контролировали работу земских начальников и их уездных съездов на уровне губернии.
4 марта 1906 г. Николай II подписал указ о создании землеустроительных комиссий. П.А. Столыпин видел в них механизм осуществления аграрных преобразований и считал, что деятельность нового института должна способствовать сокращению общинного землевладения. Указом определялись две их основные задачи: 1) помощь Крестьянскому поземельному банку при приобретении земли крестьянами; 2) содействие населению в устранении недостатков существовавшего землевладения и землепользования. Для непосредственного выполнения этих обязанностей и создавались уездные и губернские землеустроительные комиссии [12, с. 2; 19, № 27478].

На основании материалов, собранных Особым совещанием о нуждах сельскохозяйственной промышленности 1902 г., а также сведений от губернаторов Комитет по землеустроительным делам, созданный при Главном управлении землеустройства и земледелия (ГУЗиЗ), считал нецелесообразным открывать землеустроительные комиссии во всех уездах империи в 1906 г., так как это было бы слишком обременительно для бюджета. П.А. Столыпин полагал, что комиссии смогут выполнять свои функции только при полной укомплектованности кадровым составом. Поэтому в 1906 г. было решено открыть комиссии только там, где в них будет наибольшая потребность [24, с. 12]. В первую очередь это относилось к 32 губерниям Европейской части России, в том числе Виленской, Витебской, Гродненской, Минской и Могилевской $[12$, с. $8 ; 20$, л. 46]. Комитет посчитал необходимым создать комиссии во всех уездах в 18 губерниях, а в 14 губерниях в некоторых уездах признавалось возможным временно отложить землеустройство крестьян либо деятельность Крестьянского поземельного банка не была значительно востребована местным населением. В результате до 1 января 1907 г. в 5 белорусских губерниях было открыто 28 уездных землеустроительных комиссий [7, л. 31-31 об.; 11, с. 131; 15; 20, л. 46, 50-51], а до конца года уездные комиссии работали на всей территории края (46 уездов). В 1907 г. комиссии были открыты еще в 190 уездах империи, а к 1912 г. действовали в 463 уездах 47 губерний России [12, с. 10-11]. Таким образом, на территории Беларуси новые органы 
создавались более быстрыми темпами, чем в целом по империи.

Практически всю землеустроительную работу проводили уездные комиссии. Они состояли из уездного предводителя дворянства (председатель), председателя уездной земской управы или его заместителя, члена окружного суда, непременного члена комиссии, земского начальника соответствующего участка, а также трех землевладельцев, избираемых уездным земским собранием, и трех представителей от крестьян, назначаемых из числа кандидатов, избранных волостными сходами (ст. 1, п. 1) [18, № 27478]. В соответствии с законом от 29 мая 1911 г. в состав уездной комиссии был введен четвертый выборный представитель от крестьян - от волости, по которой рассматривалось дело. При этом важным фактором была их дисциплинированность и политическая благонадежность. Например, минский губернатор Я.Е. Эрдели направил в уездные комиссии письма с просьбой сообщить, «какого направления будут избраны в местные землеустроительные комиссии крестьяне, то есть трудовики или благоразумные». В ответах указывалось: «Избранные кандидаты - люди благонадежные» [20, л. 74-75]. В белорусских губерниях в связи с отсутствием земств до 1911 г. землевладельцы назначались губернатором по представлению уездного предводителя дворянства. В Витебской, Минской и Могилевской губерниях с 1911 г. они избирались в соответствии с законодательством для земских губерний. Включение в состав комиссий земских начальников было обусловлено тем, что эти чиновники по своим прямым обязанностям должны были знать географические особенности местности, демографическую ситуацию, а также основные сложности поземельных отношений в своем участке.

Для объединения действий уездных комиссий, наблюдения за их деятельностью и разрешения возникавших в них разногласий создавались губернские землеустроительные комиссии $[18$, № 27478]. Подготовка к созданию губернских комиссий началась с 1906 г., а их открытие - с 1907 года. Сначала функции губернских землеустроительных комиссий возлагались на губернские присутствия. В Витебской, Минской и Могилевской губер- ниях губернские землеустроительные комиссии начали свою работу в мае - июне 1907 г. [20, л. 51]. В Гродненской и Виленской губерниях функции губернских землеустроительных комиссий до издания закона от 29 мая 1911 г. выполняли губернские присутствия [10, л. 11 ; 13 , c. 25].

В заседаниях губернских комиссий в качестве председателя принимал участие губернатор. Членами были: губернский предводитель дворянства, начальник управления земледелия и государственных имуществ (или его товарищ, то есть заместитель), председатель губернской земской управы, председатель окружного суда, член окружного суда, непременный член губернского присутствия, губернский землемер, член уездной землеустроительной комиссии, а также 6 членов по избранию губернским земским собранием (по трое от землевладельцев и от крестьян). Однако в Витебской, Минской и Могилевской губерниях из-за отсутствия земств представители от населения назначались комитетами по делам земского хозяйства, а затем кандидатуры утверждались губернатором [11, с. 131-132].

В Виленской и Гродненской губерниях при губернских присутствиях были открыты специальные отделения по делам землеустройства. В их заседаниях участвовали губернатор (председатель), члены губернского присутствия (управляющий казенной палатой, начальник управления земледелия и государственных имуществ, прокурор окружного суда, непременные члены присутствия), а также на правах членов присутствия: управляющий отделением Крестьянского поземельного банка губернии, губернский землемер, уездные предводители дворянства и непременные члены уездных землеустроительных комиссий. При необходимости приглашались и другие лица. В 1911 г. здесь были созданы губернские землеустроительные комиссии по общему образцу $[10$, л. $1-5 ; 16$, л. 4-5]. Однако изза отсутствия земств в названных губерниях губернатор сам «приглашал» в состав комиссии представителей от землевладельцев. Так, в состав Гродненской губернской землеустроительной комиссии, открытой 15 октября 1911 г., губернатор пригласил в качестве представителя от землевладельцев бывшего гродненского вице-губернатора А.А. Ознобишина 
и волостного старшину ближайшей к г. Гродно Озерской волости И.А. Сытого [16, л. 7 об. -8$]$.

Работа землеустроительных комиссий была напрямую связана с деятельностью местных отделений Крестьянского поземельного банка. Закон от 4 марта 1906 г. привел к увеличению количества крестьян, которые хотели приобрести дополнительные земли для своего хозяйства при помощи банка. Например, в пяти белорусских губерниях с 1893 по 1906 г. банки приняли 1204 заявления о желании покупки сельскохозяйственных угодий, а за один только 1907 г. - 3260 , в том числе 1916 (58,8 \%) были одобрены [11, с. 132]. Землеустроительные комиссии должны были подготовить и передать в банк ряд документов для решения вопроса о выдаче займа. Земскому начальнику поручался сбор сведений и составление заключения, передававшиеся им на рассмотрение комиссии, которая решала вопрос по ходатайству. Землеустроительные комиссии обсуждали вопросы о целесообразности приобретения банком предлагаемых для продажи имений, делали заключение по их оценке, выясняли действительную стоимость купленного Крестьянским банком поместья. При выделении участков под хутора ими проводились все необходимые землеустроительные работы, составлялись планы разделения, проводилась разбивка крупных участков на части. Комиссии осуществляли посреднические функции между продавцами и покупателями, помогали последним при подготовке документов, организовывали мелиоративные и землемерные работы и др. В результате при содействии местных органов управления в 1907-1909 гг. в пяти белорусских губерниях банк выдал крестьянам 5148 займов для приобретения 183310 дес. земли, а в 19101912 гг. - 13394 займа на 313549 десятин. В итоге за 1905-1914 гг. крестьяне края приобрели (за вычетом продажи) 998961 дес. земли [2, с. 382].

В целом по Российской империи с 1 января 1907 по 1 января 1915 г. банком было продано 4083 тыс. дес., в том числе крестьянам в единоличное владение хуторскими и отрубными участками - 3216 тыс. дес., или $78,2 \%$, и сельским общинам - 682 тыс. десятин [12, с. 36-37].
11 ноября 1908 г. П.А. Столыпин и главноуправляющий землеустройством и земледелием А.В. Кривошеин отметили, что за два года повсеместно были достигнуты значительные результаты в развитии у крестьян стремления к личной собственности на землю. При этом, по мнению названных чиновников, в западных губерниях укрепление наделов в личную собственность, разверстание целых поселений на хутора и отруба было подготовлено условиями подворного владения и более высокой земледельческой культурой, а переход крестьян к хуторам и отрубам начался еще до реформы. Поэтому здесь новые хуторяне сравнительно быстро переходили к многопольной системе, обычной среди мелких частных владельцев. Передача опыта организации именно хуторских и отрубных хозяйств предполагалась правительством полезной для крестьян. Они могли увидеть возможности реальных соседних хозяйств, а не помещичьих имений, убедиться в возможности использования новых, улучшенных форм ведения хозяйства на их собственных угодьях [3, л. 2-4].

На местах для выяснения условий агрономической помощи собирались губернские агрономические совещания в составе всех членов губернской землеустроительной комиссии, губернской земской управы (в земских губерниях), агрономических специалистов и вообще знающих лиц по приглашению председателя. Возглавлял совещание губернатор (председатель) или назначенные им заместители. Правительство признавало, что от распространения сельскохозяйственных знаний зависело «все наше экономическое будущее» [3, л. 4-5]. Поэтому в начале июля 1908 г. губернаторам 26 губерний, где стремление крестьян к переходу на хуторские и отрубные хозяйства было более определенным, был разослан циркуляр ГУЗиЗ. В число таких губерний первыми вошли Виленская, Ковенская, Минская, Могилевская и Витебская. Затем шли Смоленская, Псковская, Киевская, Черниговская, Волынская, Херсонская, Полтавская, Самарская и др. Циркуляром предлагалось изучение существовавших в каждой губернии крепких мелких хозяйств, вне зависимости от их принадлежности. Рекомендовалось выяснить, какие изменения в хозяйстве 
введены владельцами по сравнению с обычными хозяйствами крестьян определенной местности, какие новации стали выгодными и полезными, с какими трудностями столкнулись при переходе к новым формам хозяйствования и т. д. [3, л. 5-6].

На местном уровне, в губерниях, сбор таких сведений предлагалось возложить на земства. Однако на территории Беларуси подобную информацию собирали земские начальники, что стало особенностью региона, и передавали в губернские присутствия, которые обобщали ее и направляли губернским совещаниям [3, л. 6-10]. В 1908 г. такие совещания были созваны в Витебской и Могилевской губерниях [5, л. 1, 12, 23]. При этом МВД возложило на непременных членов губернских присутствий обязанность «относиться с нарочитым вниманием и особой энергией к работе этих учреждений» [6, л. 21].

Для реализации реформы необходимо было разъяснять населению ее положения и условия. Эта задача в белорусских губерниях была возложена на земских начальников. Так, земский начальник 3-го участка Лидского уезда Виленской губернии. А.А. Сейферт в 1907-1908 гг. проводил разъяснительную работу среди крестьян своего участка и, в частности, подготовил к переходу на хутора две деревни Конявской волости - Рудня и Кошеты, часто беседовал с жителями участка о сельскохозяйственной культуре, знакомил с публикациями, раздавал брошюры Л. Нобеля «Польза молочного хозяйства», А. Биндерлинга «Беседы о земледелии» и др. [14, л. 2].

На уездные съезды земских начальников были возложены обязанности по утверждению удостоверительных актов на землю. Эти институции должны были заверять акты на закрепление земли за отдельными домохозяевами, составленные земскими начальниками или волостными сходами. Недовольные могли приносить в уездный съезд жалобы на такие решения или на приговоры сельских сходов (ст. 4-5). Сами акты хранились в канцелярии уездного съезда, и каждый мог требовать сделать копию или выписку о праве собственности на свой участок. Если уездный съезд принимал решение о несоответствии закону постановления земского начальника, то оно отправлялось последнему для исправления в соответствии со сделанными съездом замечаниями или исправлялось самим съездом (ст. 26-28) [19, № 33743]. Так, в Витебской и Могилевской губерниях в личную собственность были укреплены участки 139420 дворов, или 63 \% [2, с. 375].

В соответствии с «Правилами о землеустройстве целых сельских обществ», утвержденными 19 марта 1909 г. Комитетом по землеустроительным делам, губернские присутствия рассматривали и выносили постановления о землеустройстве целых сельских обществ, давали определения по делам о разделах многонаселенных однопланных общин, а также о выделах земли выселкам и частям поселений и др. [12, с. 20-21].

По утверждению К.Ю. Таранович, в первые годы работы землеустроительных комиссий в местностях с преобладанием малоземельных хозяйств переход на хутора и отруба не был широко распространен из-за недостаточного количества земли, которой владели домохозяева. В свою очередь, у обеспеченных владельцев не было необходимости в землеустроительных работах. Наиболее благоприятными условия для разверстания на единоличные участки были в губерниях со средней величиной наделов у большинства крестьян (8-10 дес.). Именно такие хозяйства преобладали в пяти северо-западных губерниях. Например, в 1911 г. в Витебской губернии в среднем площадь крестьянского надела составляла 9 дес., Виленской - 13,5 дес., Минской - 9,1 дес., Могилевской - 8,2 дес. [20, л. 126]. При этом комиссии отмечали, что переселившиеся на хутора и отруба крестьяне не желали возвращаться к общинной или чересполосно-подворной форме землевладения. Наоборот, в отчетах комиссий подчеркивалось: «...С выходом на хутора во всех селениях без исключения пашни значительно увеличиваются. Каждый хозяин стремится расчистить и распахать в своем участке все, что только может быть распахано: кустарники, бывшие пастбища, плохие покосы. С ростом пашни в той же степени возрастает и посевная площадь. Благодаря близости и кучности полей, обработка производится своевременно и тщательнее, пашня удобряется ровнее» [20, л. 127]. 
Особенностью землеустроительных работ в белорусских губерниях являлось создание хуторских и отрубных хозяйств. На их долю приходился 81 \% всех земельных преобразований, а во внутренних губерниях империи только 30 \% [20, л. 133]. Комиссии рассматривали ходатайства крестьян о переходе на хутора и отруба в первую очередь. Помимо предоставляемой землеустроительными комиссиями технической и материальной поддержки, стимулировавшей такие преобразования, хуторскому расселению на территории Беларуси способствовал ряд факторов. Во-перых, крестьяне были подготовлены к такому ведению хозяйства. Во-вторых, длительное время были распространены хутора латышских и немецких колонистов, показывавших местному населению положительный пример ведения фермерского хозяйства. Кроме того, земельное устройство, укоренявшееся комиссиями, не противоречило юридически или фактически существовавшей здесь форме владения.

В результате в 1907-1916 гг. в пяти белорусских губерниях на надельной земле площадью более 1147 тыс. дес. было создано 113,8 тыс. хуторских и отрубных хозяйств. Это составило более 18,7 \% площади надельного землевладения и 10 \% всех крестьянских дворов [2, с. 375]. Такое соотношение, с одной стороны, между количеством отрубных и хуторских хозяйств и, с другой, площадью земли в их собственности является свидетельством того, что с общиной в основном порывали среднеземельные крестьяне. Малоземельные составили основную массу переселенцев, продав свои земельные участки зажиточной части белорусской деревни. Наиболее быстрыми темпами разверстание надельной земли на хутора и отруба шло в Витебской и Могилевской губерниях. Это было связано с тем, что до реформы на этой территории преобладало общинное землевладение. Отметим, что среди губерний Российской империи по количеству созданных за 1906-1915 гг. единоличных владений Витебская занимала 8-е место, а Могилевская - 14-е. В среднем одно частное владение составляло чуть более 10 дес. земли [20, л. 131-132]. Таким образом, на отрубные и хуторские владения переселялись преимущественно малоземельные и среднеземельные крестьяне.
Отдельным направлением реформы было переселение крестьян из центральных и западных районов в Сибирь, Среднюю Азию, на Дальний Восток. Таким способом правительство рассчитывало снизить остроту земельного вопроса. В этом направлении также проводилась комплексная работа. Так, именно местные учреждения по крестьянским делам знакомили сельское население «со всеми законами, правилами и льготами по ходачеству и переселением, а также с порядком распоряжения земельным имуществом на родине» $[13$, с. 21]. Например, в губернские присутствия каждую неделю отправлялись данные о количестве свободных душевых долей на переселенческих участках, а затем эти сведения сообщались населению земскими начальниками. В свою очередь, землеустроительные комиссии снабжали ходоков, отправлявшихся в места предполагаемого переселения для осмотра на местности и закрепления участков, справочными книжками. В изданиях описывались губернии и области Сибири и Дальнего Востока, содержались сведения по оплате проезда и провозу багажа, о переселенческих пунктах, где можно было получить медицинскую помощь и купить продовольственные товары, прилагалась карта, а также размещалась другая полезная информация. Правительство стремилось избежать скопления людей на переселенческих пунктах, поэтому движение переселенцев было распределено на маршруты. В частности, в Сибирь и на Дальний Восток по маршруту № 4 с обустроенными переселенческими пунктами в Смоленске, Вязьме, Протопопово (г. Тула), Коршуновке (г. Моршанск), Пензе направлялся поток из Виленской, Витебской, Гродненской, Минской и Могилевской губерний [20, л. 138,141$]$.

С этой же целью комиссии распределяли переселявшихся по очередям. Для каждой очереди было определено конкретное время посадки и район следования. Например, в первую очередь, с 10 по 25 марта ежегодно, выдвигались переселенцы из Витебской, Минской и Могилевской губерний. Они направлялись в Енисейский, Забайкальский, Иркутский, Приморский, Тургайско-Уральский районы. Вторая очередь двигалась с 26 марта по 12 апреля в Амурский район. В третью очередь (вре- 
мя посадки с 14 до 29 апреля ежегодно) перевозка из указанных губерний не производилась. В Томский и Семипалатинский районы с 1 по 15 мая направлялась четвертая очередь. С 17 по 31 мая в Тобольский и Акмолинский районы следовала пятая очередь. С 1 по 20 июня могли отправляться все переселенцы, по каким-либо причинам не отправившиеся раньше [20, л. 143-144].

Динамика переселенческого движения с 1896 по 1914 г. отражена в сборниках, изданных в 1910 и 1916 гг. Переселенческим управлением. Первоначально учитывались только переселенцы, двигавшиеся через Челябинск и Сызрань. Ехавшие через Тюмень в статистику не попали [22]. В 1916 г. в статистику были уже включены переселенцы, зарегистрировавшиеся в Челябинске и Сызрани, а также следовавшие через переселенческие пункты в Тюмени по Тюмень-Омской дороге, в Полетаеве - по Троицкой дороге и в Ртищеве для переселявшихся в северо-западную часть Уральской области [23]. Переселенцы из пяти белорусских губерний регистрировались в Екатеринбурге (Тюмени), Ершове (Ртищеве), Сызрани и Челябинске.

В целом за 1906-1914 гг. из пяти белорусских губерний на Дальний Восток и в Сибирь двинулись 352814 переселенцев. Из них по переселенческим удостоверениям от землеустроительных комиссий следовали 301381 человек (85 \%). Самостоятельно направлялись $15 \%$. Большинство составляли семейные переселенцы, направлявшиеся на предварительно закрепленные ходоками участки [22, с. 31-35; 23, с. 30-34].

Некоторые из переселявшихся в 19061914 гг. не смогли укрепиться на новом месте, 37166 (10,5\%) человек вернулись обратно. В итоге 315648 (89,5 \%) выходцев из пяти белорусских губерний обустроились на Дальнем Востоке и в Сибири. Таким образом, это направление реформы можно считать достаточно результативным. В Витебской и Могилевской губерниях земельный голод ощущался более остро, поэтому они лидировали по количеству переселенцев $[22$, с. $31-35 ; 23$, c. 30-34]. В свою очередь, в Виленской и Гродненской губерниях правительство сдерживало переселенческое движение по политическим причинам с целью предотвращения ослабления русского элемента, поэтому масштабы переселения здесь были ниже. При этом в пяти белорусских губерниях $93 \%$ ходоков и $85 \%$ переселенцев направлялись в сибирские и дальневосточные губернии с официальными документами и потому пользовались льготными железнодорожными тарифами. Это означает, что крестьяне пяти белорусских губерний редко прибегали к самовольному движению при переселении и в преобладающем количестве случаев обращались за помощью в землеустроительные комиссии [20, л. 156-157].

Результаты. Реализация столыпинской реформы была невозможна без согласованных действий всех структурных элементов системы местного государственного управления, проводивших аграрную политику. Именно на территории Беларуси новые органы землеустроительные комиссии - начали свою работу раньше, чем во многих других регионах империи, из-за их востребованности. Более быстрые темпы перехода к хуторскому и отрубному землевладению, использование новых форм ведения хозяйства на территории Беларуси - все это было обусловлено несколькими факторами. Главным являлось преобладание подворного землевладения на большей части региона. Именно эти традиции давали местному населению возможность быстрее увидеть положительные стороны преобразований. Поэтому разъяснительная работа, проводимая земскими начальниками и членами землеустроительных комиссий, деятельность по продаже банковских земель, земеустройству, выделу наделов в собственность и переходу к новым формам ведения хозяйства встречали отклик у крестьян региона.

\section{СПИСОК ЛИТЕРАТУРЫ}

1. Волгирева, Г. П. Земельные реформы начала и конца XX века в России / Г. П. Волгирева, О. А. Пасько. - Томск : Демос, 2014. - 203 с.

2. Гісторыя сялянства Беларусі са старажытных часоў да нашых дзён : у 3 т. - Т. 2 : Гісторыя сялянства Беларусі ад рэформы 1861 г. да сакавіка 1917 г. / 3. Е. Абезгаўз [i інш.] ; пад рэд. В. П. Панюціча. - Мінск : Бел. навука, 2002. - 552 с.

3. Дело о передаче в местные учреждения разработки вопросов по землеустройству и улучше- 
нию крестьянского хозяйства // Российский государственный исторический архив (РГИА). Ф. 1276. -Оп. 4, 1908 г. - Д. 511. - 13 л.

4. Дело о переходе крестьян д. Кублики Кобринского уезда от шнурового к хуторскому землевладению // Национальный исторический архив Беларуси в г. Гродно (НИАБ в г. Гродно). - Ф. 18. Оп. 1. - Д. 598. -5 л.

5. Дело об образовании особых совещаний по применению закона 9 ноября 1906 года // РГИА. - Ф. 1291. - Оп. 31, 1908 г. - Д. 362. - 234 л.

6. Дело об увеличении окладов содержания непременным членам губернских и губернских по крестьянским делам присутствий // РГИА. Ф. 1278. - Оп. 2. - Д. 2057. - 52 л.

7. Дело об учреждении уездных землеустроительных комиссий в Гродненской губернии // НИАБ в г. Гродно. - Ф. 18. - ОП. 1. - Д. 478.- 157 л.

8. Ежегодник Главного управления землеустройства и земледелия по Департаменту земледелия и Лесному департаменту. - 1911. - № 5. - СПб. : Тип. В. Ф. Киршбаума, 1912. - 1027 с.

9. Емельянова, Т. В. Деятельность губернских и уездных землеустроительных комиссий по осуществлению аграрной (столыпинской) реформы / Т. В. Емельянова // Известия СПбГАУ. - 2017. № 1 (46). - С. 238-244.

10. Журналы Виленского губернского присутствия по землеустроительному отделу за 1908 год // Литовский государственный исторический архив (LVIA). - Ф. 386. - Оп. 1. - Д. 5. - 263 л.

11. Жытко А. П. Структура і функцы органаў мясцовага дзяржаўнага кіравання / А. П. Жытко, С. А.Талмачова [і інш.] // Грамадска-палітычнае жыццё ў Беларусі, 1772-1917 гг. / А. У. Унучак [i інш.] ; рэдкал.: В. В. Даніловіч (гал. рэд.) [i інш.]. Мінск : Беларуская навука, 2018. - С. 86-135.

12. Комитет по землеустроительным делам. Краткий очерк за десятилетие: 1906-1916. - Петроград : Т-во Р. Годике и А. Вильборг, 1916. -62, VII, [10] с., [15]л.

13. Краткий обзор десятилетней деятельности крестьянских учреждений Виленской губернии, преобразованных по закону 12 июля 1889 года (1 декабря 1903 - 1 декабря 1913) / сост. Виленским губернским присутствием. - Вильна : Губернская тип., 1913. - 37 с. // Научно-справочная библиотека РГИА. Печатная записка 14926.

14. О результатах ревизий крестьянских учреждений Виленской губернии // РГИА. - Ф. 1291. Оп. 31, 1908 г. - Д. 28. -425 л.

15. Памятная книжка Минской губернии на 1908 год. - Минск : Тип. С.А. Некрасова, 1907. - 200, $163,[3] \mathrm{c}$.

16. Переписка с Главным управлением землеустройством и земледелием и др. об открытии Грод- ненской губернской землеустроительной комиссии // НИАБ в г. Гродно. - Ф. 32. - Оп. 1. - Д. 225.- 19 л.

17. Полное собрание законов Российской империи (ПСЗРИ). Собрание третье. Т. 9 (1889). - СПб. : Гос. тип., 1891. - 1490 с.

18. ПЗСРИ. Собрание третье. Т. 26 (1906). СПб. : Гос. тип., 1909. - [2], 1141, [29] с.

19. ПСЗРИ. Собрание третье. Т. 30 (1910). СПб. : Гос. тип., 1913.-[2], 1408, 29 с.

20. Таранович, К. Ю. Деятельность землеустроительных комиссий по реализации столыпинской аграрной реформы в Беларуси (1906-1917 гг.) : дис. ...канд. ист. наук / Таранович Кристина Юрьевна. - Минск, 2016. - 239, [2] л.

21. Труды местных комитетов о нуждах сельскохозяйственной промышленности : в 58 т. - СПб. : Тип. Тов-ва «Народная польза», 1903-1904. - Т. 4 : Виленская губерния. - 1903. - IV, 212 с. ; Т. 5 : Витебская губерния. - 1903. - 534 с. ; Т. 11 : Гродненская губерния. - 1903. - V, 544 с. ; Т. 21 : Минская губерния. - 1903. - VIII, 435 с. ; Т. 22 : Могилевская губерния. $-1903 .-\mathrm{V}, 167 \mathrm{c}$.

22. Турчанинов, Н. Итоги переселенческого движения за время с 1896 по 1909 гг. (включительно) / Н. Турчанинов. - СПб. : Изд. Переселен. упр., 1910. - [2], VIII, 85 c.

23. Турчанинов, Н. Итоги переселенческого движения за время с 1910 по 1914 гг. (включительно) / Н. Турчанинов, А. Домчарев. - Петроград : Переселен. упр., 1916. - [6], 81 с.

24. Узаконения, относящиеся до землеустроительных комиссий, образованных в силу именного высочайшего указа 4 марта 1906 года. - Казань : Лито-тип. И.Н. Харитонова, 1906. - 64 с.

\section{REFERENCES}

1. Volgireva G. P., Pasko O. A. Zemelnye reformy nachala $i$ kontsa $X X$ veka $v$ Rossii [Land reforms in Russia at the turn and end of the XX century]. Tomsk, Izd-vo Demos, 2014. 203 p.

2. Gistoryja sjaljanstva Belarusi sa starazhytnyh chasow da nashyh dzjon: u 3 t. T. 2: Gistoryja sjaljanstva Belarusi ad rjeformy $1861 \mathrm{~g}$. da sakavika $1917 \mathrm{~g}$. [The history of the peasantry of Belarus from ancient times to the present days: in 3 vol. Vol. 2. The history of the peasantry of Belarus from the reform of 1861 to March 1917]. Minsk, Bel. navuka, 2002. 552 p.

3. Delo o peredache v mestnye uchrezhdenija razrabotki voprosov po zemleustrojstvu i uluchsheniju krest'janskogo hozjajstva [The case of transferring to local institutions the development of issues on land management and improvement of the peasant economy]. Rossijskij gosudarstvennyj istoricheskij arhiv [Russian state historical archive], f. 1276, op. 4. 1908, d. 511. 131. 
4. Delo o perehode krest'jan d. Kubliki Kobrinskogo uezda ot shnurovogo k hutorskomu zemlevladeniju [The case of the transition of the peasants of the Kubliki village of the Kobrin county from the cord to the farm land tenure]. Nacional'nyj istoricheskij arhiv Belarusi v g. Grodno [National historical archive of Belarus in Grodno], f. 18, op. 1, d. 598.51 .

5. Delo ob obrazovanii osobyh soveshhanij po primeneniju zakona 9 nojabrja 1906 goda [The case of the formation of special conferences on the application of the law of the $9^{\text {th }}$ of November 1906]. Rossijskij gosudarstvennyj istoricheskij arhiv [Russian state historical archive], f. 1291, op. 31, 1908, d. 362.2341 .

6. Delo ob uvelichenii okladov soderzhanija nepremennym chlenam gubernskih i gubernskih po krest'janskim delam prisutstvij [The case of an increase in the salaries of the constant members of the provincial and provincial peasant offices]. Rossijskij gosudarstvennyj istoricheskij arhiv [Russian state historical archive], f. 1278, op. 2, d. 2057. 521.

7. Delo ob uchrezhdenii uezdnyh zemleustroitel'nyh komissij v Grodnenskoj gubernii [The case of the establishment of county land management commissions in the Grodno province]. Nacional'nyj istoricheskij arhiv Belarusi v g. Grodno [National historical archive of Belarus in Grodno], f. 18, op. 1, d. 478.1571.

8. Ezhegodnik Glavnogo upravlenija zemleustrojstva i zemledelija po Departamentu zemledelija i Lesnomu departamentu [Yearbook of the General Directorate of Land Management and Agriculture for the Department of Agriculture and the Forestry Department], 1911, no. 5. Saint Peterburg, Tip. V.F. Kirshbauma, 1912.1027 p.

9. Emel'janova T.V. Dejatel'nost'gubernskih $i$ uezdnyh zemleustroitel'nyh komissij po osushhestvleniju agrarnoj (stolypinskoj) reformy [Activity of provincial and district land management commissions for the implementation of agrarian (Stolypin) reform]. Izvestiya SPbSAU, 2017, no. 1 (46), pp. 238-244.

10. Zhurnaly Vilenskogo gubernskogo prisutstvija po zemleustroitel'nomu otdelu za 1908 god [Logs of the Vilna provincial office on the land management department for 1908]. Litovskij gosudarstvennyj istoricheskij arhiv [Lithuanian state historical archive], f. 386, op. 1, d. 5. 2631.

11. Zhytko A. P., Talmachova S. A. Struktura $i$ funkcyi organaw mjascovaga dzjarzhawnaga kiravannja [Structure and functions of local government bodies // Gramadska-palitychnae zhyccjo w Belarusi, 1772-1917 gg. Social and political life in Belarus, 1772-1917]. Minsk, Belaruskaya navuka, 2018. 86-135 pp.
12. Komitet po zemleustroitel'nym delam. Kratkij ocherk za desjatiletie: 1906-1916 [Committee on land management affairs. A brief sketch of a decade: 1906-1916]. Petrograd, T-vo R. GodikeiA. Vil'borg, 1916. 62, VII, [10] p.

13. Kratkij obzor desjatiletnej dejatel'nosti krest'janskih uchrezhdenij Vilenskoj gubernii, preobrazovannyh po zakonu 12 ijulja 1889 goda (1 dekabrja 1903-1 dekabrja 1913) [A brief overview of the ten-year activity of institutions on peasantry of the Vilna province, transformed according to the law of the $12^{\text {th }}$ of July 1889 (the $1^{\text {st }}$ of December 1903 - the $1^{\text {st }}$ of December 1913)]. Vil'na, Gubernskaja tip-ja, 1913. 37 p. Nauchno-spravochnaja biblioteka RGIA. Pechatnaja zapiska 14926 [Scientific reference library of the RSHA. Printed note no. 14926].

14. Orezul'tatah revizij krest'janskih uchrezhdenij Vilenskoj gubernii [About the results of audits of peasant institutions in the Vilna province]. Rossijskij gosudarstvennyj istoricheskij arhiv [Russian state historical archive], f.1, op. 31, 1908, d. 28. 4251.

15. Pamjatnaja knizhka Minskoj gubernii na 1908 god [Commemorative book of the Minsk province for 1908]. Minsk, Tip. S.A. Nekrasova, 1907. 200, 163, [3] p.

16. Perepiska s Glavnym upravleniem zemleustrojstvom i zemledeliem i dr. ob otkrytii Grodnenskoj gubernskoj zemleustroitel'noj komissii [Correspondence with the Main Directorate of land management and agriculture and etc. about the foundation of the Grodno provincial land management commission]. Nacional'nyj istoricheskij arhiv Belarusi v g. Grodno [National historical archive of Belarus in Grodno], f. 32, op. 1, d. 225. 191.

17. Polnoe sobranie zakonov Rossiiskoi imperii. Sobranie tretye. T. 9 (1889) [Full collection of laws of the Russian Empire. Coll. 3. Vol. 9 (1889)]. Saint Peterburg, Gosudarstvennaia tip., 1891. 1490 p.

18. Polnoe sobranie zakonov Rossiiskoi imperii. Sobranie tretye. T. 26 (1906) [Full collection of laws of the Russian Empire. Coll. 3. Vol. 26 (1906)]. Saint Peterburg, Gosudarstvennaia tip., 1909. [2], 1141, [29] p.

19. Polnoe sobranie zakonov Rossiiskoi imperii. Sobranie tretye. T. 30 (1910) [Full collection of laws of the Russian Empire. Coll. 3. Vol. 30 (1910)]. Saint Peterburg, Gosudarstvennaia tip., 1913. [2], 1408, 29 p.

20. Taranovich K.Ju. Dejatelnost zemleustroitelnyh komissij po realizacii stolypinskoj agrarnoj reformy $v$ Belarusi (1906-1917 gg.): diss. ...kand. ist. nauk [Activities of the Land Use Planning Committees Connected with Implementation of the Stolypin Agrarian Reform in Belsrus (1906-1917): Cand. hist. sci. diss]. Minsk, 2016. 239, [2]1.

21. Trudy mestnyh komitetov o nuzhdah sel'skohozjajstvennoj promyshlennosti: v $58 \mathrm{t}$. [Proceedings of local committees on the needs of the agricultural industry: in 58 vol]. Saint Petersburg, Tip. 
Tov-va «Narodnaja pol'za», 1903-1904. Vol. 4, 1903, IV, 212 p.; Vol. 5, 1903, 534 p.; Vol. 11, 1903, V, 544 p.; Vol. 21, 1903, VIII, 435 p.; Vol. 22, 1903, V, 167 p.

22. Turchaninov N. Itogi pereselencheskogo dvizhenija za vremja s 1896 po $1909 \mathrm{gg}$. (vkljuchitel'no) [The results of the resettlement movement for the period from 1896 to 1909 (inclusive)]. Saint Peterburg, Izd. Pereselen. upr., 1910. [2], VIII, 85 p.

23. Turchaninov N. Itogi pereselencheskogo dvizhenija za vremja s 1900 po $1914 \mathrm{gg}$. (vkljuchitel'no) [The results of the resettlement movement for the period from 1900 to 1914 (inclusive)]. Petrograd, Izd. Pereselen. upr., 1916. [6], 81 p.

24. Uzakonenija, otnosjashhiesja do zemleustroitel'nyh komissij, obrazovannyh v silu imennogo vysochajshego ukaza 4 marta 1906 goda [Legislation relating to land management commissions formed by virtue of a nominal imperial decree of the $4^{\text {th }}$ of March 1906]. Kazan', Lito-tip. I.N. Haritonova, 1906. 64 p.

\section{Information About the Author}

Svetlana A. Tolmacheva, Candidate of Sciences (History), Associate Professor, Head of the Department of the History of Belarus and Slavic Nations, Belarusian State Pedagogical University named after Maxim Tank, Sovetskaya St, 18, 220030 Minsk, Republic of Belarus, tolmachova.sv@yandex.ru, https://orcid.org/0000-0002-6708-0282

\section{Информация об авторе}

Светлана Александровна Толмачева, кандидат исторических наук, доцент, заведующий кафедрой истории Беларуси и славянских народов, Белорусский государственный педагогический университет им. Максима Танка, ул. Советская, 18, 220030 г. Минск, Республика Беларусь, tolmachova.sv@yandex.ru, https://orcid.org/0000-0002-6708-0282 